\title{
Provision Quality, Customer Approval and Reliability in Banking Sector: A Case Study of Pakistan
}

\author{
Mehwish Kanwal \\ Ex (MBA)Scholar Department of Bussiness Administration, \\ Allama Iqbal Open University, Islamabad Campus, Pakistan
}

\begin{abstract}
The principal purpose of the research article is to measure the quality of service offered by private banks operating in Pakistan. Moreover, it tries to investigate the relationship between provision quality, customer approval, and reliability. In order for a bank offer to reach customers, there is a need for services. These services depend on the type of product and it differs in various organizations. Service can be defined as an intangible offer by one party to another in exchange for money for Service quality in the management and marketing literature is the extent to which customers' perceptions of service meet and exceed their expectations. Thus service quality can intend to be how customers are served in an organization that could be good or poor. A reliability program may give a customer advanced access to new products, special sales coupons or free merchandise. Our study shows the three basic aspects of a customer in the banking sector which are service quality, customer satisfaction and banking loyalty in the banking sector. The findings of our study show that most of our respondents are well satisfied with banking services provide by different commercial and Islamic banks such as HBL, UBL, NBP, MCB, ALFALAH etc. in Islamabad. The services provided by the banks particularly ATM.The customers very praise machines. The reliability provided to customers by the banks was also outstanding and most of the respondents were satisfied from that but there were also some significant problems in these banking sectors for customers which should be handled as soon as possible for their excellent services we also find out that the banking policies for customer services and to maintain loyalty with customer should be enhanced more precisely.
\end{abstract}

Keywords: Provision Quality, Customer Approval, Customer's Reliability.

DOI: $10.7176 / \mathrm{EJBM} / 12-1-04$

Publication date: January $31^{\text {st }} 2020$

\section{INTRODUCTION}

Customer is highly essential for businesses especially after the marketing era launched during the 1950s. During this era, companies started to focus on customer needs and produced more customized products. Now customer satisfaction is becoming a great topic of interest for researchers and organizations around the world. Every organization tries to achieve customer satisfaction in order to make a profit and grow. In this study, the focus is on customer satisfaction.

\section{Customer Satisfaction}

Customer is those individuals who buy our products and services. Thus, the customer is an

essential stakeholder of the organization who provides income to the organization. Marketing literature differentiates between customer and consumer as the customer is someone who purchases your product; while, the consumer is someone who consumes the product.

\section{Statement of the Problems}

1: Offensive and poor attitude and behavior on the bank's staff in their dealings with actual and potential customers.

2: Inadequate facilities and equipment required to provide new banking services.

3: Absence of frequent training programs for the staff to shape up their attitude towards customers.

4: Unduly long processes in responding to customer's needs.

5: Excessive competition from banks that perform commercial banking services.

Service Quality

Services play an essential role in any country's economy. There are various services offered by service-oriented firms. Generally, service refers to any intangible act or performance which is offered by one party to another. Generally, services are offered for exchange of money or similar. The concept of service quality has gained much interest in marketing literature, and the work of Zeithaml is one of the famous ones in this domain. Service quality is about the quality of services offered by an organization to its customers.

\section{Customer Reliability}

The customer reliability program is about rewarding customers for their repeated purchases. It can be in the form of free merchandise, points system, or special sales coupons which can be redeemed by the customer. Mostly, the customer reliability program is based on customer registration with the firm and recording sales made by that customer over the period. Organizations such as airlines or restaurants offer customer rewards for their repeated purchases. 


\section{Objectives Of The Study}

1: To evaluate the level of service quality in the Banking sector.

2: To examine customer pleasure in the Banking sector.

3: To examine banking reliability with the customer in the banking sector.

4: To find out the problems faced by customers in the banking sector.

\section{RESEARCH METHODOLOGY}

This section provides details about the research methodology.

\section{Study Area}

The role of commercial banks in the Economic Development of a country cannot be defined. Banks have always been playing a role in bringing out a country from depression with its monetary and fiscal tools, for example, taxation, interest rate etc. Therefore the banks of Pakistan as a whole have been taken as a study area.

\section{Target Population}

In our survey, our target population is different Banks of Islamabad.

\section{Sampled Population}

For meeting the need of my survey, I collected information from the people of Islamabad. The respondents belonged to different areas of Islamabad.

\section{Method Of Inquiry}

The questionnaire method is used through simple random sampling to meet the need of the survey. The questionnaire has given to each person and they filled it correctly.

\section{Sample Size}

For the survey, I take the size of 30 from different individuals of Islamabad.

\section{Duration Of The Study}

The study continued for approximately six months, where planning for review, data collection and report had been framed.

\section{Limitations Of The Study}

There were many limitations of the study, such as time was short. Due to the shortage of time, the researcher had to shorten the sample size and research area. It was hard to collect data from Islamic banking customers as it was only possible in the Islamic banks and customers were not much willing to give information because of time shortage or because of the bank where it does not look good to give interviewed.

\section{DATA ANALYSIS}

Data collected through the above material instrument were tabulated, analyzed, and interrupted. The analysis had done through SPSS by using.

\section{Descriptive Analysis}

Table 1: Gender

\begin{tabular}{|l|c|c|}
\hline & Frequency & Percent \\
\hline Male & 21 & 70.0 \\
\hline Female & 9 & 30.0 \\
\hline Total & 30 & 100.0 \\
\hline
\end{tabular}

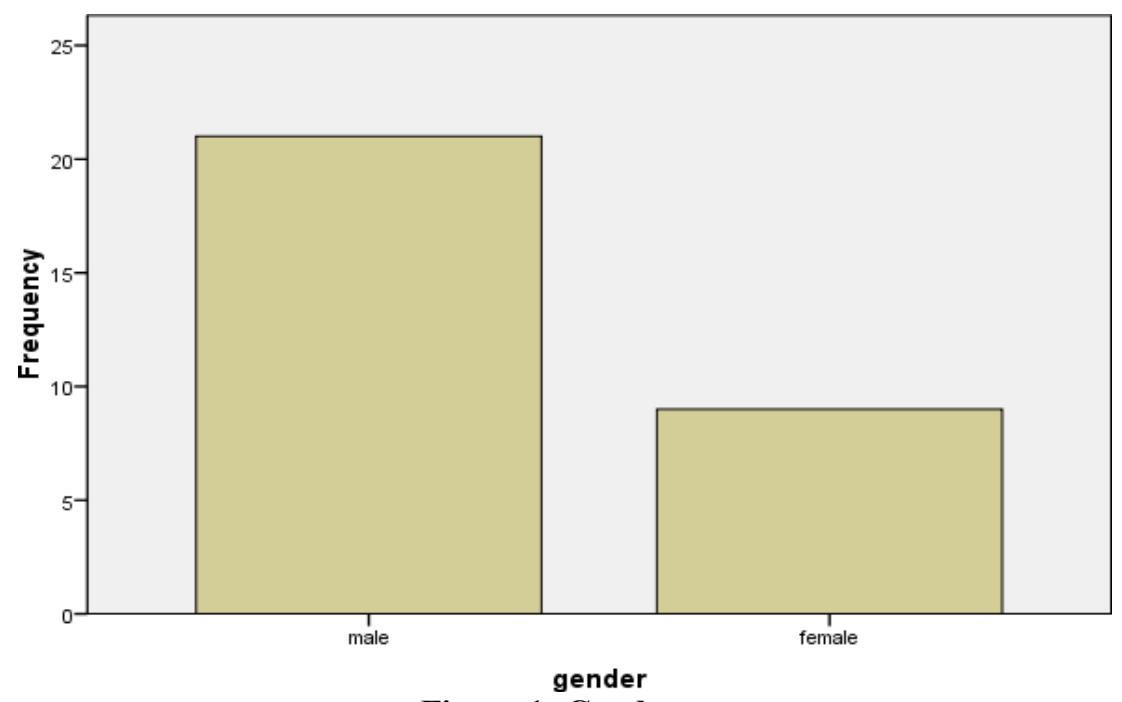

Figure 1: Gender 
The above table and figure show the gender distribution of the respondents. According to the results, 21(70\%) out of 30 are male and $9(30 \%)$ out of 30 respondents are female.

Table 2: Age of respondent

\begin{tabular}{|l|c|c|}
\hline & Frequency & Percent \\
\hline up to 20 years & 1 & 3.3 \\
\hline between 20 to 30 years & 20 & 66.7 \\
\hline above 30 years & 9 & 30.0 \\
\hline Total & 30 & 100.0 \\
\hline
\end{tabular}

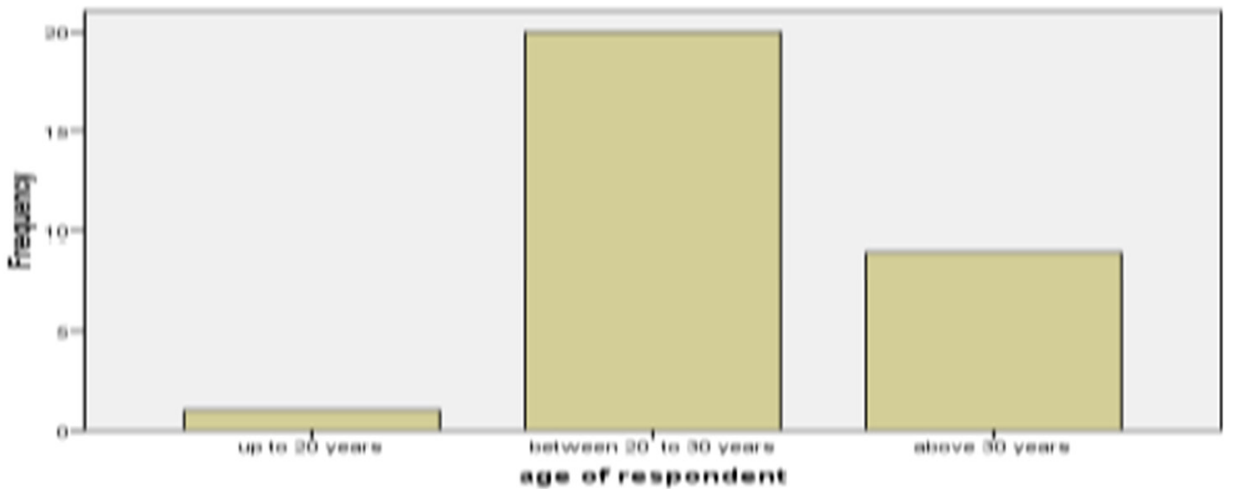

Figure 2: Age

The above table and figure show the distribution of the age of respondents the results show that the age of respondents up to 20 years is $1(3.3 \%)$, the age of respondents between 20 years and 30 years are $20(66.7 \%)$ and age above 30 years is $7(30 \%)$.

Table 3: Occupation of respondent

\begin{tabular}{|l|c|c|}
\hline & Frequency & Percent \\
\hline government job & 8 & 26.7 \\
\hline private job & 12 & 40.0 \\
\hline Student & 9 & 30.0 \\
\hline Housewife & 1 & 3.3 \\
\hline Total & 30 & 100.0 \\
\hline
\end{tabular}

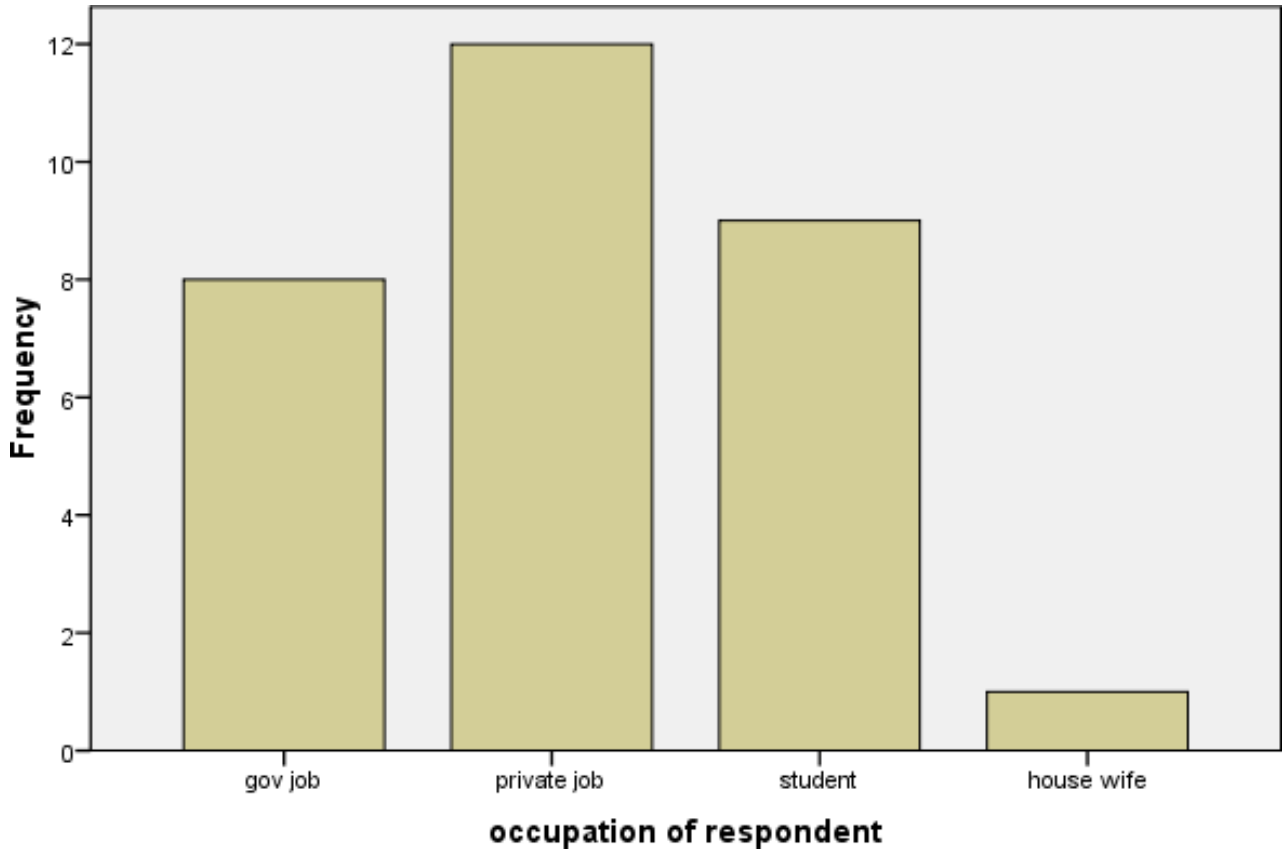

Figure 3: Occupation

The above table and figure show the distribution of occupation of respondents. According to results, the 
respondents who have government jobs are $8(26.7 \%)$, private job respondents are $12(40 \%)$, students are $9(30 \%)$ and housewife is $1(3.3 \%)$.

\begin{tabular}{|l|c|c|}
\multicolumn{2}{|c|}{ Table 4: Qualification } \\
\begin{tabular}{|l|c|c|}
\hline & Frequency & Percent \\
\hline Metric & 1 & 3.3 \\
\hline Fsc,b.com & 3 & 10.0 \\
\hline Ba/BSc & 12 & 40.0 \\
\hline MSc/MBA & 14 & 46.7 \\
\hline Total & 30 & 100.0 \\
\hline
\end{tabular}
\end{tabular}

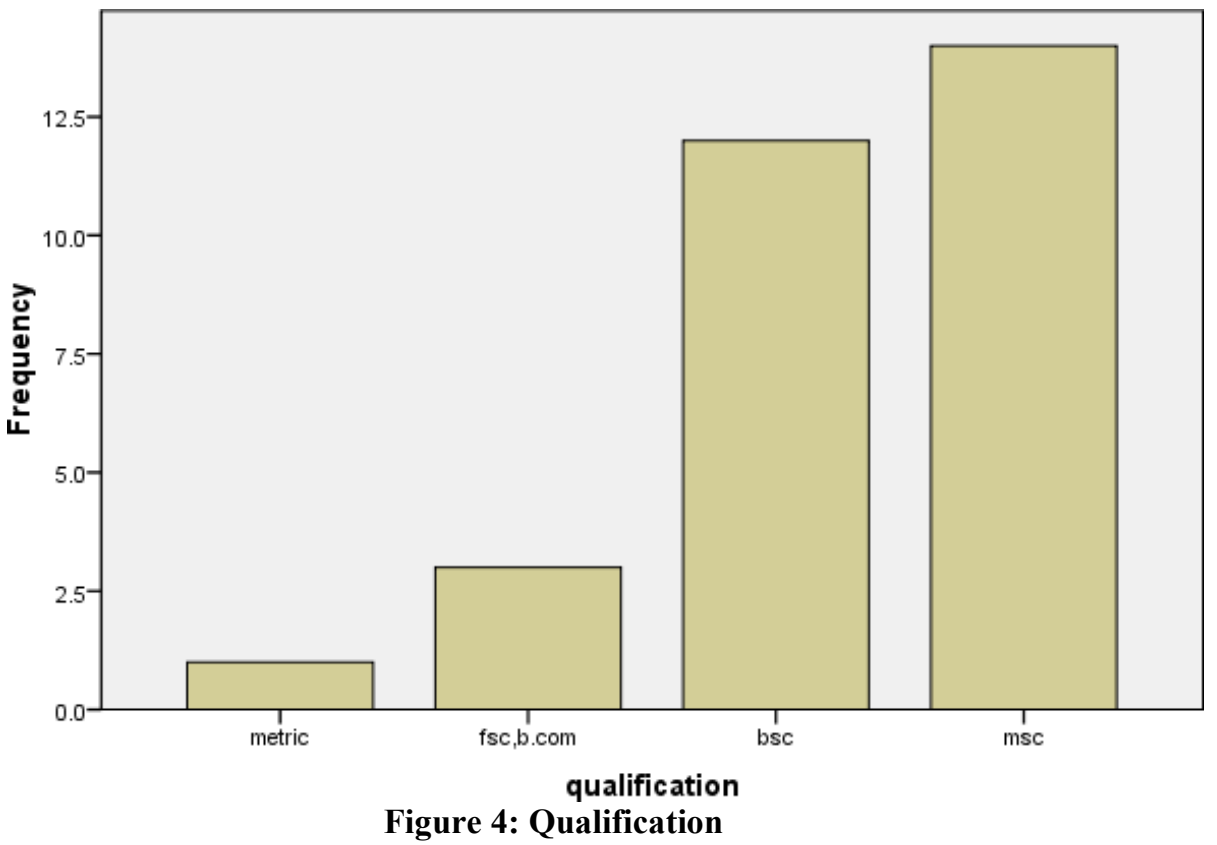

The above table and figure show the qualification distribution of respondents the results shows that the qualification of respondents up to metric is $1(3.3 \%)$, FSc is $3(10 \%)$, BSc is $12(40 \%)$ and respondents who have master level qualification are 14(46\%).

\section{CONCLUSION}

The study conducted on endowment excellence, customer pleasure, and reliability in the banking sector. After the completion of the study, the following conclusion based on descriptive statistics can be deducted. From the result of the present day, we found that the majority of the respondents were male, out of 30 respondents, $21(70 \%)$ are male and 9(30\%) respondents are female. Most of the respondents have an age between 20 to 30 years which are $20(67 \%)$ out of 30 samples. The occupation of the respondents was different in which most of the respondents belong to the private job which is $12(40 \%)$ out of total samples. The qualifications of most of the respondents have Master or MBA level education which are 12 (46\%) out of total respondents. We also find out that different respondents have accounts in different banks of Peshawar sadder and most of the respondents belong to the conventional type of bank which is $21(70 \%)$ out of total samples. Most of the respondents have current account $24(80 \%)$. The respondents also suggest that the bank does not charge unnecessarily charges. I concluded

That the ATM facility is more available on banks than other facilities in banks, and the respondents said that the particular bank caters to all our banking needs.

One of the basic objectives of our study was to find out the satisfaction level of a customer on banking networking. We concluded that $25(80 \%)$ of respondents out of 30 were satisfied with banking networking. We also concluded that the first problem to the customer from the banking side was ATM related problems. Most of the respondents said that the wide branch networking of banks comes first in our minds related to their bank, in which they have an account. We concluded that the banking services of particular banks were outstanding which is $15(50 \%)$ of the total sample. Most of the respondents $16(53 \%)$ out of 30, visit banks 1 to 5 times in a month. We also concluded that most of the respondents trust completely on online banking security services. Human contact is also vital for banking relations.

We concluded that the main problem related not to visit the particular bank branch was waiting in the bank's branch and also a distance from the branch from home is the main problem of not giving to banks. We also 
concluded that personal information in banks preserved in a particular bank. In the last, we concluded that most of the respondents $26(76.6 \%)$ out of 30 , are satisfy with the bank policies for the betterment of customer services.

\section{REFERENCES}

Anderson, E. W., \& Sullivan, M. W. (1993). The antecedents and consequences of customer satisfaction for firms. Mark. Anderson, E. W., \& Sullivan, M. W. (1993).

Anderson, H., \& Jacobsen P. N. (2000). The antecedents and consequences of customer satisfaction for firms. Mark. Sci. Creating Loyalty: Its Strategic Importance in Your Customer Strategy. In S. A. Brown (ed.), Customer Relationship Management.

Angur, M. G., Nataraajan, R. \& Jahera, J. S. (1999). Service Quality in the banking industry: an assessment in a developing economy. International Journal of Bank Marketing.

Anthanassopoulos, A., Gounaris, S., \& Sathakopoulos, V. (2001).

Anton, J. (1996).Customer Relationship Management: Making Hard Decisions with Soft Numbers. Upper Saddle River: Prentice-Hall.

Bearden, W. O. \& Teel, J .E. (1983). Selected Determinants of Consumer Satisfaction and Complaint Reports.

Behavioral responses to customer satisfaction: an empirical study. European. J. Mark.

Bitner, M. J., Booms, B .H. \& Tetreault, M .S. (1990). Relationship marketing of services- growing interest, Emerging Perspectives. Journal of the Academy of Marketing Science.

The Service Encounter: Diagnosing Favorable and Unfavorable Indents. Journal of Marketing.

Bleomer, J., \& Ruyter, K. D. (1998). On the relationship between store image, store satisfaction and store loyalty. Eur. J. Mark.

Bloemer, J., de-Ruyter, K. \& Wetzels, M. (1999). Linking perceived service quality and service loyalty: A multidimensional perspective. European Journal of Marketing.

Bontis, Nick, Booker, Lorne, D., \& Serenko, A. (2007).The mediating effect of organizational reputation on customer loyalty and service recommendation in the banking industry. Manage. Decision.

Johnson, M. D. \& Fornell, C. (1991). A Framework for comparing customer satisfaction across individuals and product categories. Journal of Economic Psychology, 12 (2): 267-286.

Jumaev, M., Prof. Dr. Kumar, D. M. and Hanaysha, J. R. M. (2012). Impact of relationship marketing on customer loyalty in the banking sector. Far East Journal of Psychology and Business, 6(3): 36-55.

Juran, J.M. (1988). Juran's quality control handbook. McGraw-Hill, New York, NY. Khalid, S., Mahmood, B., Abbas, M. \& Hussain, S. (2011). Customer satisfaction with service quality in conventional banking in Pakistan. International Journal of Marketing Studies, 3(4): 165-174.

Kheng, L.L., Mahamad, O., Ramayah, T., M. \& Rahim, Mosahab, R. (2010). The impact of service quality on customer loyalty: a study of banks in Penang. Malaysia. International Journal of Marketing Studies, 2(2): $57-$ 66

Kotler, P., \& Keller, K. L. (2006). Marketing Management (pp. 402). New Delhi, India: Prentice- Hall. Lewis, M. (2004). The influence of loyalty programs and short-term promotions on customer retention. Journal of Marketing Research, 41(3): 281-292.

Mesay Sata Shanka Bank Service Quality, Customer Satisfaction and Loyalty in Ethiopian Banking Sector. (2012) 